\title{
Affinity Ionic Liquids for Chemoselective Gas Sensing
}

\author{
Albert Chang ${ }^{1}$, Hsin-Yi Li ${ }^{1}$, I-Nan Chang ${ }^{2}$ and Yen-Ho Chu ${ }^{1, *}$ \\ 1 Department of Chemistry and Biochemistry, National Chung Cheng University, 168 University Road, \\ Minghsiung, Chiayi 62102, Taiwan; changalbertalbertchang@gmail.com (A.C.); \\ lanbarla0708@gmail.com (H.-Y.L.) \\ 2 ANT Technology Co., Ltd., 137, Section 1, Fushing South Road, Taipei 10666, Taiwan; ant.tech@msa.hinet.net \\ * Correspondence: cheyhc@ccu.edu.tw; Tel.: +886-5272-9139
}

Received: 29 August 2018; Accepted: 15 September 2018; Published: 18 September 2018

\begin{abstract}
Selective gas sensing is of great importance for applications in health, safety, military, industry and environment. Many man-made and naturally occurring volatile organic compounds (VOCs) can harmfully affect human health or cause impairment to the environment. Gas analysis based on different principles has been developed to convert gaseous analytes into readable output signals. However, gas sensors such as metal-oxide semiconductors suffer from high operating temperatures that are impractical and therefore have limited its applications. The cost-effective quartz crystal microbalance (QCM) device represents an excellent platform if sensitive, selective and versatile sensing materials were available. Recent advances in affinity ionic liquids (AILs) have led them to incorporation with QCM to be highly sensitive for real-time detection of target gases at ambient temperature. The tailorable functional groups in AIL structures allow for chemoselective reaction with target analytes for single digit parts-per-billion detection on mass-sensitive QCM. This structural diversity makes AILs promising for the creation of a library of chemical sensor arrays that could be designed to efficiently detect gas mixtures simultaneously as a potential electronic in future. This review first provides brief introduction to some conventional gas sensing technologies and then delivers the latest results on our development of chemoselective AIL-on-QCM methods.
\end{abstract}

Keywords: volatile organic compound; chemoselective gas analysis; ionic liquid; quartz crystal microbalance

\section{Introduction}

Gas, one of the four fundamental states of matter, has a unique place in the eye of human. To say the least, the air human inhale contains oxygen that serves as an oxidizing agent in cellular respiration to release adenosine triphosphate (ATP), the molecular unit of currency for our everyday activity. Also, the carbon dioxide exhaled by human is the main ingredient for plants to undergo photosynthesis and release oxygen back to the atmosphere. Analysis of gases is of great importance for a myriad of applications in health, safety, military, industry and environment. For example, breath volatile organic compounds (VOCs) have found immense value in noninvasive disease diagnosis and metabolism monitoring [1-8]. Food industry uses gas sensing technologies for quality control of fruit ripeness and detection of meat spoilage [9-13]. Analysis of indoor air quality domestically and industrially has been implemented for monitoring hazardous and asphyxiant gases [14-16]. Moreover, selective detection of gases is used as means of both homeland securities for early detection of chemical warfare agents (CWAs) [17] and industrial regulation for greenhouse emission [18]. As a result, it is obvious that, in sync with the advance of science technology, increase in human activities, improvement in life quality and health, demands for gas analysis will only continue to grow. However, to provide quantification analysis of gases is rather difficult than it may sound. 
Unlike liquid or solid, gas is shapeless and invisible to the naked human eye due to the large discretion between each molecule, allowing them to move quickly and freely. To add on, the abundance of gaseous molecules such as single atom gases (e.g., noble gases: $\mathrm{He}, \mathrm{Ni}$ and $\mathrm{Ar}$ ), single type of atom gases (e.g., $\mathrm{O}_{2}$ and $\mathrm{N}_{2}$ ) or multiple atom gaseous molecules (e.g., $\mathrm{CH}_{4}$ and $\mathrm{CO}_{2}$ ) augments the difficulty for specific trace detection. Therefore, considering the complexity of the constituents in gas mixtures along with other properties, the importance to develop capable gas sensing methods has never been more on demand.

Gas analysis has long been an important field of study that can be dated back to Hippocrates for his study on breath aroma [19]. Yet, due to the lack of sufficient detection methods and tools, the development of gas analysis had largely stand pat at qualitative analysis. With the advances in science and technology, scientists had started to employ new devices capable of providing quantitative analysis. Most notably, in 1950s, Keeling and coworkers deployed an infrared gas analyzer to give birth to the renowned graph, the Keeling Curve, which was first to provide the direct linkage of human activities to climate change in continuous measurement of carbon dioxide concentration for 20 years [20]. In 1971, Pauling and coworkers spent 3 years to develop a gas-liquid chromatography system that permits the determination of more than 250 substance in breath and urine vapor, signaling the start of modern breath analysis [21]. Since then, great strides have been made in the development of analytical methods, many of which are powerful tools that provide comprehensive information on gas analysis. A brief survey of the available tools is provided in Figure 1. However, given the wide ranges available, not one is without flaw and can be satisfied for all needs. In this review, general description on common gas sensing methods is provided, along with ionic liquids (ILs), the materials that have garnered our interest due to their unique properties. Finally, a detail account is reported on affinity ionic liquid (AIL) by quartz crystal microbalance (QCM), a chemoselective sensing method with great potential for commercial use.

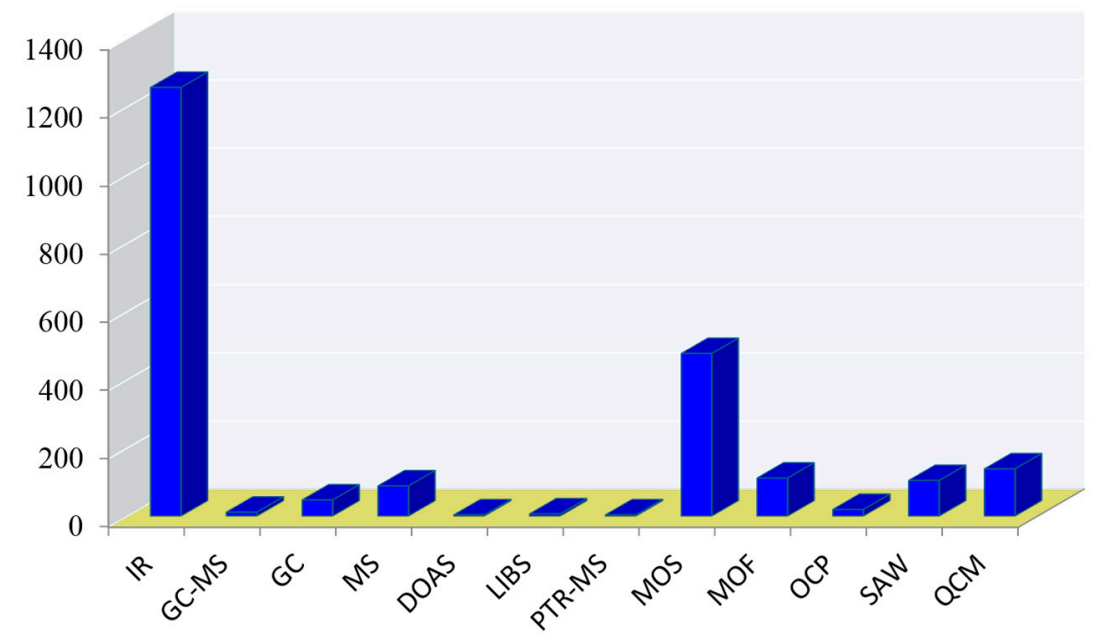

Figure 1. Number of articles published in English on the subject of analytical tools used for "gas sensing," as determined by SciFinder on 18 August 2018. IR, infrared spectroscopy; GC-MS, gas chromatography-mass spectrometry; DOAS, differential optical absorption spectroscopy; LIBS, laser-induced breakdown spectroscopy; PTR-MS, proton-transfer reaction mass spectrometry; MOS, metal oxide semiconductor; $\mathrm{MOF}$, metal organic framework; $\mathrm{OCP}$, organic conducting polymer; SAW, surface acoustic wave; QCM, quartz crystal microbalance.

A complete sensing scheme may be divided into five parts. First, an inert reference gas such as $\mathrm{N}_{2}$ for baseline determination serves as a sample carrier. Second, a chamber is used for introduction of sample via injection or headspace sampling. Third, physical or chemical adsorption of gaseous sample on sensing substrate will result in either a physical, optical, or electrical change. Then, an analogue digital converter capable of reading the physical, optical, or electrical change will convert it into digital 
signals for computer analysis. Last, data analysis is proceeded with mathematical algorithm. A basic flow diagram is depicted in Figure 2. In this review, the bulk sensing methods are categorized into four domains: spectroscopic, spectrometric, conductivity and piezoelectricity methods. It is also worth noting that these techniques can be used together via an interdisciplinary approach. In addition, the pros and cons of the techniques will be provided for the evaluation of its selectivity, sensitivity, cost, response time and potential for real-time application.

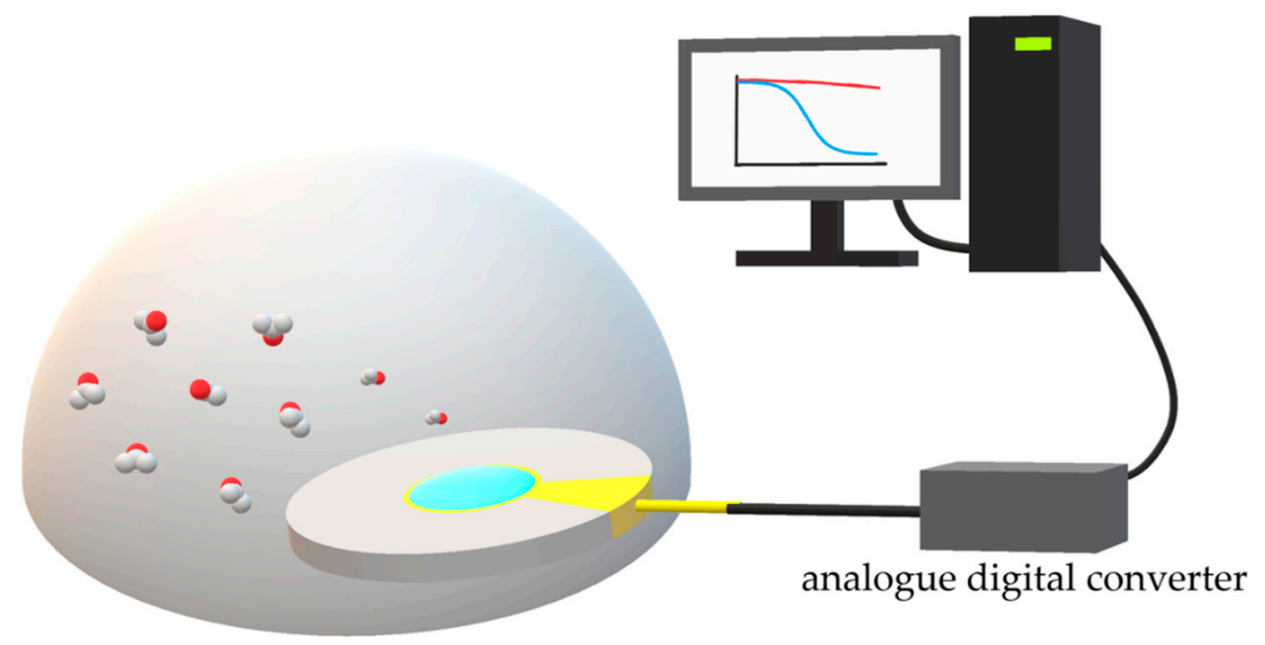

Figure 2. Schematic representation of an AIL-on-QCM gas analysis system.

\section{Gas Sensing Methods}

\subsection{Spectroscopic Methods}

There are many spectroscopic methods available in the sensing of gas molecules, including differential optical absorption spectroscopy (DOAS) and Fourier transform infrared spectroscopy (FT-IR), many of which that have been applied in field test [22,23]. The principle behind most spectroscopic gas analysis is based upon either absorption spectroscopy or emission spectroscopy. Absorption spectroscopy can be comprehended via the Beer-Lambert's law, in which the analytes can be characterized by the wavelength or frequency when absorption occurs. DOAS is an example of this and is widely used in atmospheric science for its low limit detection and good accuracy. However, DOAS suffers from interference such as $\mathrm{NO}_{2}$ and stray lights or unremoved sets in the spectra [24]. Emission spectroscopy involves the emission of photons when a molecule is excited and then returned to ground state and such an example is the laser-induced breakdown spectroscopy (LIBS). In short, spectroscopic methods have the advantage of being able to provide high selectivity and sensitivity detection. They however suffer from large instrumentation and high cost. Additional development of miniaturized instruments with affordable cost will be the next step forward.

\subsection{Spectrometric Methods}

Another conventional method for gas analysis is the gas chromatography-mass spectrometry (GC-MS). Evidence through its namesake, GC-MS is composed of two instruments: a gas chromatography system that is responsible for separation of the molecules in gaseous sample and a mass spectrometer that provides analysis of the molecules through fragmentation of the molecules by ionization to obtain mass spectra which can be then correlate to a fingerprint in the database for determination. Yet, given its advantages against other methods, the GC-MS is handicapped largely by many factors. These include the lengthy pre-concentration and analysis duration needed that make GC-MS inapplicable for real-time performance. Also, constant calibration needed by a knowledgeable operator makes it difficult to popularize [25]. Nevertheless, developments have been made in hope of refining the methods. 
The solid-phase micro extraction (SPME) is a sample pre-treatment technique developed to provide a simple, fast and solvent free preparation of the analytes to cut down the lengthy pre-concentration process [26]. A highly selective polymer coated fused-silica fiber is immersed into liquid or by exposure in the headspace for desired molecules to be adsorbed onto. This allow elimination of impedance by solvent peaks and has thus been used in many fields. Further modification of the fiber is also available to improve selectivity of the sample [27,28]. Albeit it was successful in decreasing the time needed, it is still not appropriate enough for real-time application [29,30].

Selected ion-flow tube (SIFT) is another method developed to provide better real-time analysis through alternative ionization method. It requires the chemical ionization of trace gas in air samples. The samples mixed with thermalizing buffer gas are then carried through for detection by the mass spectrometer. The method provides real-time, high sensitivity analysis of the molecules, yet, it fails to detect compounds of the same $\mathrm{m} / \mathrm{z}$ ratio. Nevertheless, it is still widely applied in fields, including an on-line quantification of VOCs at the headspace of roasted coffee by Dryahina and coworkers [31], air quality determination at drug storage areas by Doran and coworkers [29], and breath analysis by Spanel and Smith [32].

Proton-transfer reaction mass spectrometry (PTR-MS) is developed for better detection of gaseous organic compounds. It relies on the chemical ionization of gas sample by proton transfer $\left(\mathrm{H}_{3} \mathrm{O}^{+}\right)$inside the drift tube. Furthermore, a more compact instrumentation relative to SIFT with the advantages of higher sensitivity, online measurement with no requirements of pre-concentration and substance calibration is provided. Due to its proton-transfer thermodynamics, PTR-MS receives no interference with photon affinities [33]. However, this also implies that small molecules such as $\mathrm{CO}, \mathrm{CO}_{2}$ and methane cannot be detected using standard PTR-MS [34]. Although it provides superior size advantage and user-friendliness in comparison to other MS methods, it is still considered bulky. In addition, similar to SIFT it also fails to differentiate isobaric compounds.

\subsection{Conductivity Based Methods}

\subsubsection{Metal Organic Semiconductors}

Metal oxide semiconductors (MOSs) are solid-state gas detecting devices commonly used in industry for its low-cost, easy production and compact size [35,36]. The working principle of MOS is straightforward: the measurement of changes in conductivity of the metal oxide layer when interaction (e.g., redox reactions) with the surrounding environment occurred. Furthermore, high sensitivity by MOSs have led to numerous applications in gas sensing of nitrogen oxides, sulfur dioxide, hydrogen sulfide, hydrogen, ozone, VOCs and CWAs [37]. However, these sensors usually suffered from poor selectivity given their vulnerability to poisoning (e.g., ethanol, volatile sulfur compounds and humidity) [38]. In addition, high temperature $\left(>400{ }^{\circ} \mathrm{C}\right)$ required for operation and the extensive functionalization needed to further improve sensitivity also hampers its practical applications. To tackle aforementioned problems, recent research works have demonstrated promising improvements in selectivity and thermal stability through the doping of nanostructures (e.g., nanotubes and nanowires) and nanocomposites (e.g., $\mathrm{Pt}, \mathrm{Nb}, \mathrm{CeO}_{2}$, or $\mathrm{PdO}$ ) or by structure modification to increase surface area [39-41]. However, it has to be mentioned that besides the exact working mechanisms for modified MOSs via doping remain uncertain, there are still multiple aspects that needs to be addressed. In a recent review detailed by Korotcenkov and Cho, these aspects include: small to little improvements in gas sensing sensitivity, limited reproducibility due to the complex material involved, careful monitoring for large number of parameters needed for optimal control of the material and the trade-off of other parameter of sensor for improvement in selectivity and sensitivity [42]. Therefore, it is clear that further efforts need to be made in understanding the mechanism of the conductivity response occurred at the metal oxide layer. 


\subsubsection{Metal Organic Framework}

In part of their highly tunable and diverse structures, metal organic frameworks (MOFs) have garnered increasing interests over the past years. Furthermore, an outburst of development directed at numerous fields has been made, including catalysis, gas storage, separation, electric capacitors [43], energy storages [44], lithium ion batteries [45] and chemical sensors [46,47]. Given our focus in sensing tools, we will look into solely on its recent development as gas sensing methods.

As one can expect from its versatility to multiple fields, many facets of MOF properties have been experimented for possible gas sensing applications. For example, its low conductivity has led to the introduction of impedance spectroscopy in detecting different gases. Although recent success has been made in detecting ammonia and methanol, studies for better selectivity are still required for further applications [48-51]. Another application that utilized low conductivity of MOFs is its role as a chemiresistive sensor. Initial works in the field have displayed slow recovery time and high temperature requirement [52]. However, recent works by Campbell and coworkers have shed light through introducing new fabrication methods of the MOFs that were able to discriminate different VOC vapors [53]. Other works have also provided improvements through various fabrication methods [54]. Nonetheless, it should be noted that such method is still at its embryonic stage and the exact mechanisms are unknown and further studies are required [55].

Optical responses are another way MOFs can contribute in gas sensing. The method involves changes that are detected based upon either a shift in the emission spectrum, or a change in luminescence intensity. The former can be achieved by two passages: a change in solvent polarity and a change in the coordination environment of the metal ion. The latter usually involves the quenching (turn-off) or enhancement (turn-on) of photo-induced emission due to guest adsorption, with the effectiveness determined by the nature of the guest-host interactions [56]. The good sensitivity and regenerability have led to success in sensing numerous gaseous molecules, as reviewed in literature [57-59]. However further development is required for it to become fully applicable as its limitations include medium stability and the insufficient knowledge to fully address the selective nature of this method $[46,60]$. In addition, MOFs, as a selective sorbent layer, can be incorporated with mass-sensitive sensors, such as acoustic wave sensors, to achieve better selectivity of analytes.

\subsubsection{Organic Conducting Polymer}

Other than the MOSs and MOFs, organic conducting polymer (OCP) is another conventional method that has been studied extensively [61,62]. However, due to low conductivity and stability of organic materials, further fabrication is required to enhance conductivity through protonation or redox reactions, thus lead to many nanocomposite derivatives [61]. A typical OCP sensor setup constitutes of two electrodes fabricated with an insulating polymer. Modulation of the insulating polymer via spraying, spinning, or coating allows improvement in conductivity. Once exposed to gas, physical properties of the insulating substrate changes due to gaseous molecule interaction with the sensing substrate upon adsorption, thus a change in resistance occurs and measurements can be made accordingly [62]. In comparison to its inorganic conducting counterparts, OCP sensors have the advantage of short response time at room temperature with high sensitivity. Moreover, the adoption of nanocomposites increases their surface-volume-ratio to decrease response time. Thus, an array of OCPs, acting as an e-nose system, can lead to commercial applications for real-time analysis such as continuous industrial hazardous VOCs monitoring [11]. However, the improvement in response time is upstaged by the low reproducibility, selectivity and stability of the OCP structure. Furthermore, the conductivity of polymers can also be influenced by many factors, including temperature fluctuation [63]. In addition, as mimics of enzyme-substrate complexes, molecularly imprinted polymers (MIPs) can provide high selectivity for adsorption of target analytes with template-tailored cavities. These structure-directed sensing materials have been reported to successfully analyze organic molecules for determination of optimal harvest maturity in fruits. Nonetheless, the complete removal of analytes from the MIPs can be challenging and limits its productivity [64]. 


\subsection{Piezoelectric Methods}

\subsubsection{Surface Acoustic Wave}

Surface acoustic wave (SAW) sensors and bulk acoustic wave (BAW) sensors are two of the most used methods applying piezoelectric effect. SAW sensors differ from BAW sensors in that its acoustic wave mainly propagates and is confined within the near surface region, typically beneath one wavelength of the surface, whereas the wave of BAW sensors covers the whole body $[65,66]$. Nevertheless, the sensing mechanism for both is similar: the measurement and analysis of the change in wave frequency resulted from chemical or physical adsorption at the substrate.

The basic components of a SAW sensor include an input interdigitated transducer (input IDT), an output interdigitated transducer (output IDT) and a gas-sensitive coating substrate on piezoelectric substrate, as illustrated in Figure 3. An input IDT set at one end of the substrate initiates an acoustic wave that propagates along the surface of the substrate to the output IDT located on the other end. Midway through the propagation, a change of the coated region upon interactions of the gas molecules at the surface of the substrate will result in a change in the oscillation frequency. The output IDT receives the signal and outputs it to an analyzer for further computation. The interactions involved usually result to a change of mass, viscoelasticity and conductivity that will cause a time delay between the input and output IDTs, thus a wave shift that can be correlated proportionally with mass will occur, giving it its high sensitivity [67-69].

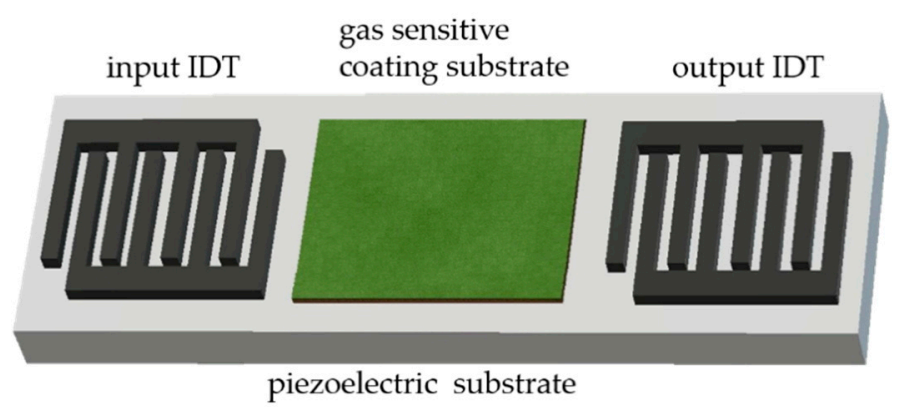

Figure 3. A brief configuration of SAW sensor. The coating substrate can be of polymer, MOS, MOF, nanocomposites and others.

The modulation of the propagation path is crucial component of a SAW-based sensor. In fact, the selectivity, sensitivity and repeatability largely depend on the sensing materials deposited on the piezoelectric substrate. Common coating materials include polymers, MOSs, MOFs, carbon nanotubes and nanoparticles. Polymer films have shown to provide short response and recovery time through physical adsorption of gas molecules. However, poor selection requires a better structure and doping. Metal oxides and MOFs, given by their high thermal stability, can detect inorganic gases and VOCs through redox reactions at high temperatures [69]. Carbon-nanotubes provide high sensitivity at room temperature due to their large surface to volume ratio, providing quick response and high adsorption capacity.

\subsubsection{Bulk Acoustic Wave}

Quartz crystal microbalance (QCM) belongs to the larger group of BAW that has been studied extensively and applied to many fields. For example, coated QCM with antibody and gold nanoparticles has been used recently for disease diagnosis and antigen detection in solutions [70-74]. Study of cells can be conducted through the examination of cell-substrate adhesion with QCM [75,76]. Furthermore, detection of environmental pollutants can also be done with QCM immunosensors [77]. The high sensitivity, stability, fast-response and low-cost characteristics have made QCM one of the most common tools applied. 
Unlike a ST-cut quartz used for SAW sensors, the QCM is made up of an AT-cut quartz sandwiched between two electrodes that is usually attached to an AC voltage, as shown in Figure 4. Upon molecular adsorption or reaction at the surface, a shift in the oscillating frequency of the quartz substrate occurs, indicative of a change in mass [78]. This working mechanism in gas phase is depicted by the Sauerbrey equation [79], where the shifting oscillation frequency can be correlated to the change of mass. Later, Kanazawa and Gordon derived a new equation for fluids based on the Sauerbrey equation, allowing further applications [80]. Similar to SAW, high sensitivity and yet low selectivity of the device also imply low tolerance to slight changes in the environment, making it highly susceptible to interference. Nevertheless, developments have been made for different uses of QCM. For example, to account for viscoelasticity common to biological molecules, inclusion of dissipation led to the introduction of QCM dissipation (QCM-D). Electrical QCM (EQCM) can be used to characterize electrochemical process. Moreover, carbon nanotubes, polymers, MOSs, MOFs and ionic liquids can also be fabricated, deposited on QCM sensors to improve performance.
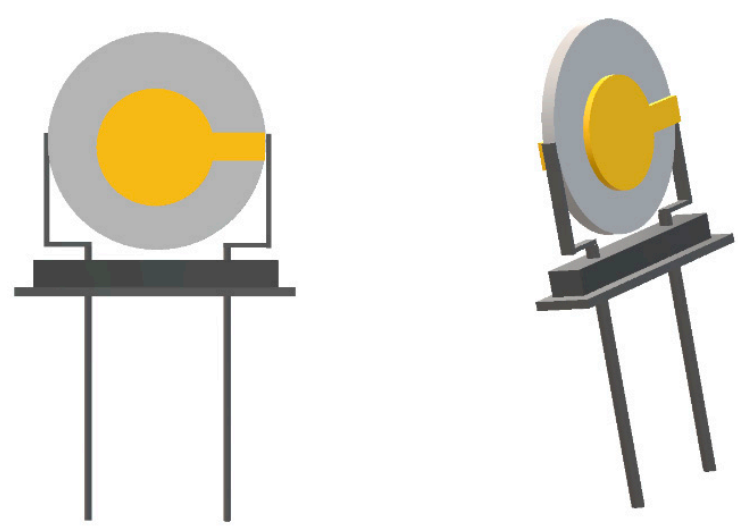

Figure 4. Schematic representation of a QCM sensor chip.

QCM-D is an often-used technique developed to provide better analysis of biological molecules but hardly applied in gas sensing. The technique relied on the monitoring of dissipation to obtain information on the structure of the substrate. This is achieved by turning off the power of the oscillating crystal and allows the oscillation decay to be measured [81-83]. A combination of the dissipative and resonant frequencies allows better estimation of the viscoelastic mass.

EQCM utilizes both amperometric sensing and mass sensing to provide cross validation in analysis. For an electrochemical experiment, three electrodes are immersed in liquid phase to perform methods such as cyclic voltammetry, differential pulse voltammetry, or square wave voltammetry. Most applications of EQCM have been focused on fields related to characterization of biological molecules and energy storage studies [84-87]. Furthermore, the introduction of ionic liquids, which provide features such as conductivity and great adsorption ability for gases, has opened a new door for new applications with EQCM. Yu and coworkers were able to employ ionic liquids as both electrolytes and sorption solvents for cross analysis of ethyl nitrobenzene [88].

Better sensing through fabricating the surface of the substrate to achieve higher selectivity and sensitivity remains to be the most dominant pathway in gas sensing with QCM. Likewise, the incorporation of MOSs and MOFs allowed improved sensitivity and selectivity through redox reaction and high surface ratio but required higher temperature and longer response time. The incorporation of molecularly imprinted polymers on QCM also showed high affinity and sensitivity toward target molecules [89]. Polymers through their porous structures are another commonly applied method for better selectivity $[9,90,91]$. Nanostructured modified QCM was also used for successful detection of plasticizer vapors, hydrogen sulfide and ammonia [92-94].

Although surface modifications of QCM provide various advantages in gas sensing, it also brought along its disadvantages to be solved. How to provide further modifications for better 
sensitivity, selectivity and reproducibility under ambient conditions for real-time applications remains as a challenging task. Ionic Liquids, with its many advantages, have the potential to fill this need.

\section{Ionic Liquids and Its Use for Adsorption Analysis of Gases on QCM}

Room temperature ionic liquids (RTILs) are liquidus molten salts at ambient temperature and composed entirely of ions. Their diverse properties in providing excellent physical, chemical, thermal and electrochemical stability, nonflammability, very low vapor pressure, good solubility and tunability have garnered them significant studies in wide range of fields (Figure 5) [95,96]. For example, tailorable physical properties such as melting points, viscosity, density, solubility and hydrophobicity have made RTILs ideal solvents for catalytic and synthetic reactions [97]. Excellent solubility of RTILs to dissolve a wide range of biomass matrices have them actively applied for extraction and separation of bioactive compounds [98]. High tailorability, good water solubility and biodegradability allow ionic liquids to gain penetration to ecological system for the purpose of drug delivery, drug synthesis, biomedical analysis in pharmaceutics and medicine [99]. The negligible volatility, high thermal stability, good electric conductivity and large electric window have enabled RTILs to serve not only as valuable electrolytes but also as precursors for carbon material electrodes [100]. Nonflammability, high thermal stability and oil-solubility satisfy the requirements for use as lubricants and lubricant additives [101]. Figure 6 gives structures of common cations and anions for ionic liquids.

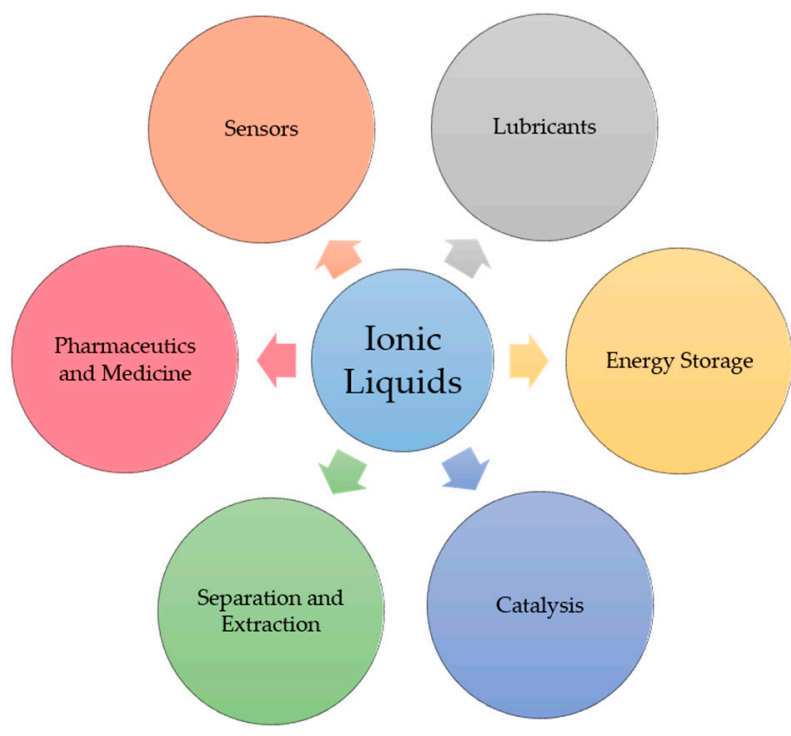

Figure 5. Common applications of ionic liquids.

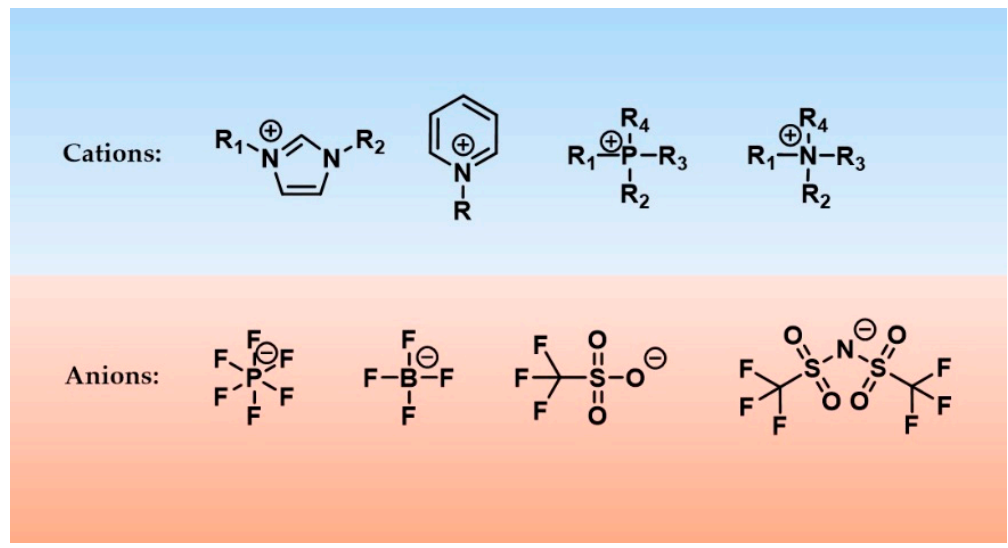

Figure 6. Common structures of ionic liquids. 
For gas sensing purpose, ILs present great value specifically in its tunable structure and high adsorption for VOCs [96,102,103]. Liang and coworkers were first to report ionic liquid on QCM for VOCs [104]. The successful detection of VOCs molecules via modification of functional groups at cations and anions displayed the tailorability of ionic liquid [104]. Later, Jin and coworkers was able to obtain promising results through employment of an IL-based sensor array on QCM [105]. Flammable organic molecules (ethanol, benzene, heptane and dichloromethane) showed linear response with increase of concentration at both room and high temperatures, though a deviation occurred at high concentration for dichloromethane due to exceed of its own vapor pressure. Statistical analysis further showed that IL-based array can be promising through providing unique response patterns for each vapor [105]. In addition, further modification of ILs and incorporation with other materials (e.g., ethyl cellulose matrix, electrospun nanofiber, or carbon nanotubes) have led to successful sensing of $\mathrm{CO}_{2}$ and $\mathrm{SO}_{2}$ [106-109].

\section{Ionic Liquid on QCM for Chemoselective Gas Sensing}

Since 2010, we have put in efforts to the development of a series of affinity ionic liquids (AILs) targeted specifically for chemoselective gas sensing [110-117]. Albeit the bulk reports from others in the past have been successful in detecting gas molecules via physical adsorption, the challenge for those methods remains for better specificity to discriminate structurally similar gas molecules from others. Chemoselective gas analysis, on the contrary, can provide a simpler solution through inducing reaction-based selection via chemical reactivity of the compounds. In addition, we have been able to use this chemoselectivity as the advantage in successfully isolating target analytes from common VOCs interference (e.g., water, methanol, acetone, ethyl acetate, hexane, acetonitrile) at room temperature. Figure 7 and Table 1 provide the structures of AILs developed in our laboratory and mechanisms employed for chemoselectivity to target gas molecules.

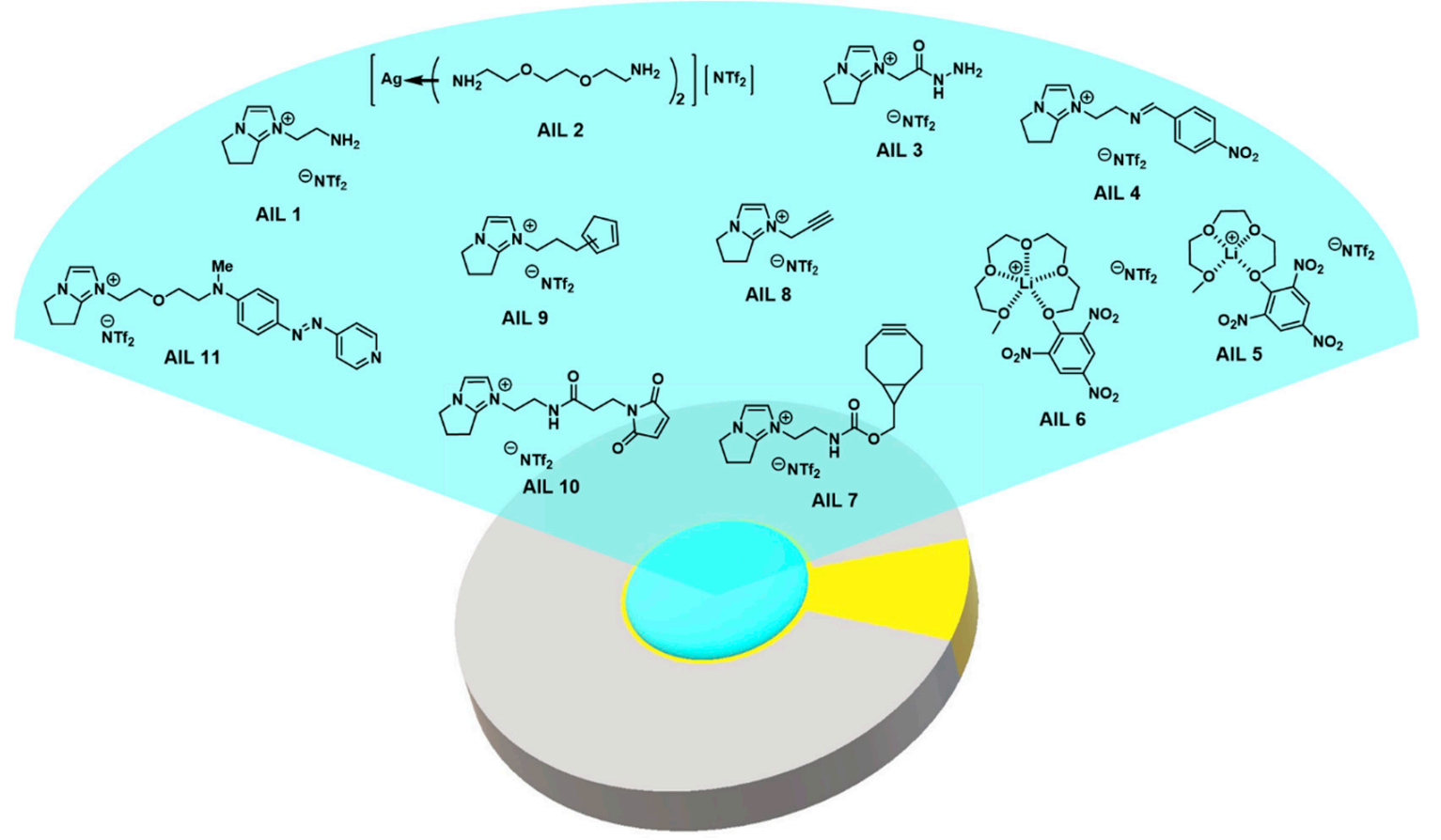

Figure 7. AILs are thin-coated on QCM electrodes for quantitative gas analysis. Here provides the AILs developed by Chu and coworkers for chemical reaction-based gas sensing. 
Table 1. A brief description of the working principles AILs employed, the targeted analytes and the sensitivity of detection.

\begin{tabular}{|c|c|c|c|c|}
\hline Ionic Liquid & Target Gas Species & Sensing Mechanism & Sensitivity of Detection & Literature \\
\hline AIL1 & aldehydes; ketones & imination & $\begin{array}{c}\Delta F=-1.0 \mathrm{~Hz}: \\
4.5 \mathrm{ppb}^{1} ; 148 \mathrm{ppb}^{2}\end{array}$ & [110] \\
\hline AIL2 & aldehydes & imination & $\begin{array}{c}\Delta F=-2.0 \mathrm{~Hz}: \\
\quad 4.6 \mathrm{ppb}^{3}\end{array}$ & [111] \\
\hline AIL3 & $\begin{array}{l}\text { acyclic and cyclic } \\
\text { ketones }\end{array}$ & $\begin{array}{l}\text { hydrazone adduct } \\
\text { formation }\end{array}$ & $\begin{array}{l}\Delta F=-1.0 \mathrm{~Hz}: \\
\quad 0.6 \mathrm{ppb}^{4}\end{array}$ & [112] \\
\hline AIL4 & amines & transamination & $\begin{array}{c}\Delta F=-1.0 \mathrm{~Hz}: \\
2.5 \mathrm{ppb}^{5}\end{array}$ & [110] \\
\hline AIL5 & amines & $\begin{array}{l}\text { nucleophilic aromatic } \\
\text { addition }\end{array}$ & $\begin{array}{l}\Delta F=10 \mathrm{~Hz}: \\
8.0 \mathrm{ppb}^{6}\end{array}$ & [113] \\
\hline AIL6 & amines & $\begin{array}{l}\text { nucleophilic aromatic } \\
\text { addition }\end{array}$ & $\begin{array}{c}\Delta F=10 \mathrm{~Hz}: \\
5.4 \mathrm{ppb}^{7}\end{array}$ & [113] \\
\hline AIL7 & azides & $\begin{array}{l}\text { Huisgen 1,3-dipolar } \\
{[3+2] \text { cycloaddition }}\end{array}$ & $\begin{array}{c}\Delta F=10 \mathrm{~Hz}: \\
5 \mathrm{ppb}^{8} ; 35 \mathrm{ppb}^{9}\end{array}$ & [114] \\
\hline AIL8 & control group & inert & inert & [114] \\
\hline AIL9 & dienes & $\begin{array}{l}\text { Diels-Alder }[4+2] \\
\text { cycloaddition }\end{array}$ & $\mathrm{N} / \mathrm{A}$ & [115] \\
\hline AIL10 & dienes & $\begin{array}{l}\text { Diels-Alder }[4+2] \\
\text { cycloaddition }\end{array}$ & $\begin{array}{l}\Delta F=-1 \mathrm{~Hz}: \\
1.5 \mathrm{ppb}^{10}\end{array}$ & [115] \\
\hline AIL11 & CWA mimics & $\begin{array}{l}\text { nucleophilic } \\
\text { substitution }\end{array}$ & $\begin{array}{l}\Delta F=5 \mathrm{~Hz}: \\
20 \mathrm{ppb}^{11}\end{array}$ & [116] \\
\hline
\end{tabular}

Sensitivity of detection with respect to ${ }^{1}$ butyraldehyde; ${ }^{2}$ 2-butanone; ${ }^{3}$ propionaldeyhyde; ${ }^{4}$ cyclohexanone with $2 \mathrm{~mol} \% \mathrm{Sc}(\mathrm{OTf})_{3} ;{ }^{5}$ propylamine with $1 \mathrm{~mol} \% \mathrm{Sc}(\mathrm{OTf})_{3} ;{ }^{6,7}$ propylamine; ${ }^{8}$ benzyl azide; ${ }^{9}$ butyl azide; ${ }^{10}$ cyclopentadiene; ${ }^{11}$ diethyl chlorophosphate.

\subsection{Chemoselective Sensing of Aldehyde and Ketone Gases}

Negligible vapor pressure and nonflammability have made room-temperature ionic liquids ideal materials to thin-coat on mass sensing transducer, QCM. The negligible vapor pressure ensures that ionic liquid does not dry out and is free of leakage during setups and experiments, while the nonflammable property allows for easy deposition of ionic liquid on QCM by dilution in methanol, which can be readily removed through short baking in oven.

In 2010, we first reported AIL1 on QCM for detection of gaseous aldehydes and ketones through the formation of a Schiff base by the imination of the amine group in AIL1 [110]. Further quantitative studies were carried out to test selectivity between two model gases of identical molecular weight, butyraldehyde and 2-butanone, that is, to differentiate aldehyde from ketone. In coherent with its reactivity towards aldehyde, butyraldehyde was able to response better with higher sensitivity of detection. Furthermore, metal containing ionic liquid AIL2 was also employed for gas analysis due to high affinity for alkylamine that resulted in easy preparation. Although AIL2 has significant drawbacks in lesser stability under light; it exhibited a better response for propionaldehyde as evidenced in Figure 8 [111]. 


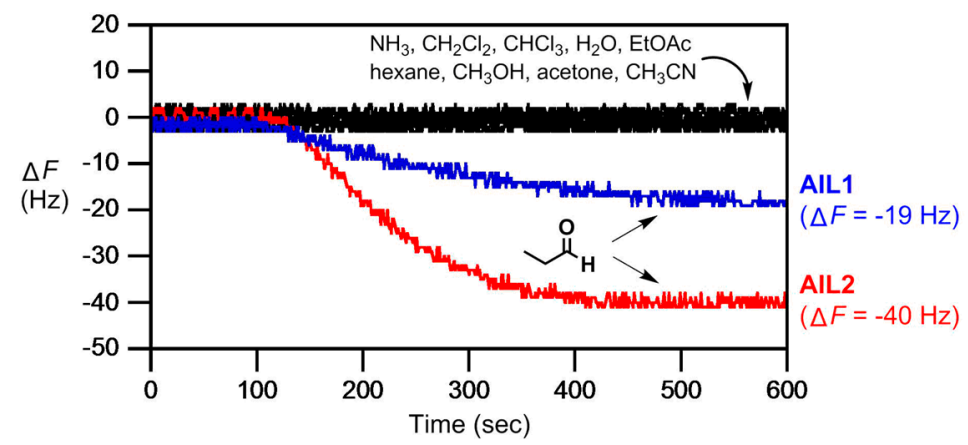

Figure 8. Chemoselective detection of common VOCs (e.g., ammonia, dichloromethane, chloroform, water, ethyl acetate, hexane, methanol, acetone, acetonitrile) and propionaldehyde gases at $100 \mathrm{ppb}$ by a multi-channeled QCM thin-coated with AIL1 and AIL2 (33 nmol each, 200-300 nm thickness). Carrier gas $\left(\mathrm{N}_{2}\right)$ had a flow rate of $3 \mathrm{~mL} / \mathrm{min}$ and analyte injection was made at $100 \mathrm{~s}$. A larger frequency change for propionaldehyde was observed for AIL2.

In 2013, we went further to study chemoselective detection of gaseous ketones by using AIL3 [112]. This is achieved by the formation of stable hydrazone adduct and a sensitive detection for low concentration of acetone ( $98 \mathrm{ppb}$ ) could be observed. Moreover, Lewis acid species were introduced to facilitate better hydrazone formation, with $2 \mathrm{~mol} \% \mathrm{Sc}(\mathrm{OTf})_{3}$ found to provide the most enhancement in detection sensitivity (Figure 9). For cyclic ketones, cyclopentanone, cyclohexanone (a signature compound emanating from C-4 explosive) and cycloheptanone were tested. Cyclohexanone displayed the largest response, in part of a greater reactivity with AIL3 due to its sterically-free chair conformation (Figure 10) [112].

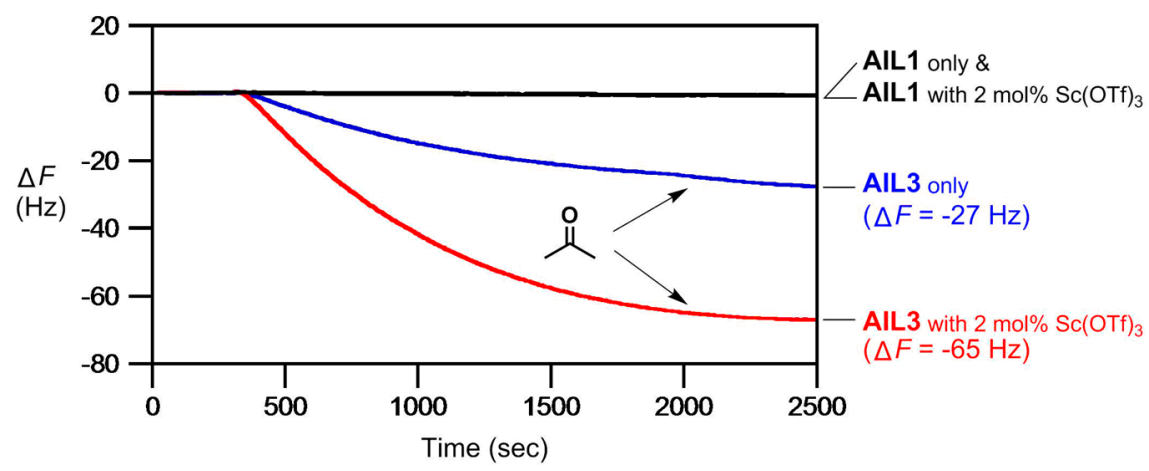

Figure 9. An ultrasensitive, $2 \mathrm{~mol} \% \mathrm{Sc}(\mathrm{OTf})_{3}$-catalyzed detection of acetone gas (58 ppb) by $9 \mathrm{MHz}$ QCM thin-coated with AIL3 (3.3 nL each, $300 \mathrm{~nm}$ thickness). AIL1 was used here as the control ionic liquid. Gaseous acetone sample was injected at $300 \mathrm{~s}$.

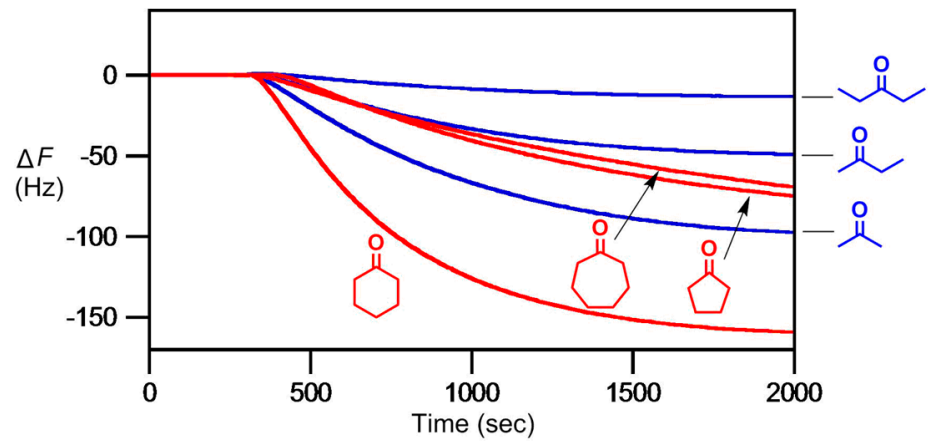

Figure 10. Chemoselective detection of acyclic and cyclic ketone gases (76 ppb each) on display by a $9 \mathrm{MHz}$ QCM thin-coated with AIL3 (3.3 nL, $300 \mathrm{~nm}$ thickness) with $2 \mathrm{~mol} \% \mathrm{Sc}(\mathrm{OTf})_{3}$. Ketone gas samples were injected at $300 \mathrm{~s}$. Frequency drops for 3-pentanone, 2-butanone, acetone, cyclopentanone, cyclohexanone and cycloheptanone were 13, 49, 97, 75, 159 and $69 \mathrm{~Hz}$, respectively. 


\subsection{Chemoselective Sensing of Amine Gases}

Modification of ionic liquids was made to demonstrate that, as an important part of VOCs as well as bacterial volatiles, amine gases could be readily captured and detected by AIL4, 5 and 6 . The working mechanism for AIL4 is the transimination reaction. Good selectivity with high sensitivity results were obtained using propylamine as a model amine gas with the addition of $1 \mathrm{~mol} \% \mathrm{Sc}(\mathrm{OTf})_{3}$ to serve as a Lewis acid catalyst [110]. In 2017, Li and Chu reported the use of AIL5 and AIL6 for sensitive detection of amine gases by means of nucleophilic aromatic addition reaction [113]. Briefly, upon the introduction of amine gases, AIL5 and AIL6 form the Meisenheimer complexes with amine molecules at the electron deficient 2,4,6-trinitrophenyl (TNP) group in ionic liquids. Here the AILs served not only as amine-specific reacting agents but also for the purpose of accelerating the reactions through the TNP-containing arene, which serves as a super electrophile, resulting in the stabilization of the Meisenheimer complexes formed. QCM results demonstrated that the sensitivity of detection for AIL5 and AIL6 with propylamine gas at frequency drop of $\Delta F=-10 \mathrm{~Hz}$ was determined to be 8.0 and $5.4 \mathrm{ppb}$, respectively. Furthermore, steric hindrance that played into the reactivity was also observed, with the primary amines responding with larger $\Delta F$ values in respect to the more sterically hindered secondary amines (Figure 11). In addition to the mass sensing provided by QCM analysis, the Meisenheimer adduct, owing to the significant changes in electronic conjugation upon nucleophilic addition by amines at the aromatic ring carbon located at TNP, was able to display an orange red color visible by the naked eye. As reported, the instantaneous response of color change in AIL6 upon exposure to amine gases when loaded on paper gives it potential for future applications as invisible ink or portable amine detector [113].

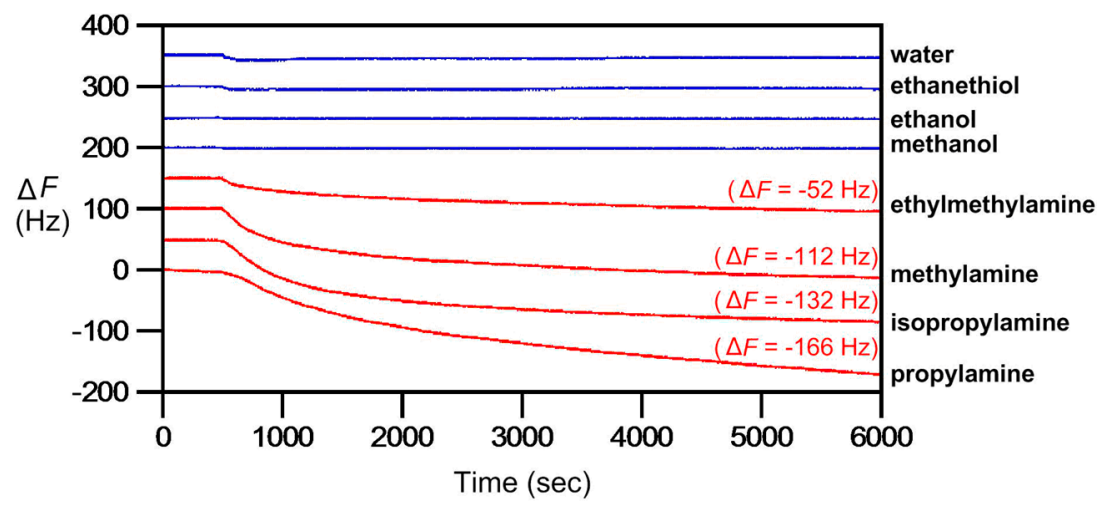

Figure 11. Chemoselective detection of water, ethanethiol, ethanol, methanol, ethylmethylamine, methylamine, isopropylamine and propylamine gases (100 ppb each) by $9 \mathrm{MHz}$ QCM thin-coated with AIL6. The carrier gas had a flow rate of $3 \mathrm{~mL} / \mathrm{min}$ and the analytes were injected at $500 \mathrm{~s}$. The sensorgrams above propylamine were purposely shifted vertically (50 $\mathrm{Hz}$ in between) for clarity.

\subsection{Chemoselective Sensing of Azide Gases}

In 2014, we demonstrated the sensitive detection of organic azide gases through strain-promoted click reactions by AIL7 on QCM. From the structure of AIL7, the strained triple bond on the cyclooctyne ring was able to display a stronger affinity for organic azide gases. Furthermore, a collection of azide gases were tested: propyl azide, pentyl azide, butyl azide, allyl azide and phenyl azide. AIL7 exhibited great reactivities to these gases and, at $\Delta F=-10 \mathrm{~Hz}$, sensitivity of detection for benzyl azide and butyl azide was $5 \mathrm{ppb}$ and $35 \mathrm{ppb}$, respectively. Furthermore, in line with the activation energy study of azides, an order of frequency change on QCM was obtained: benzyl azide > phenyl azide > allyl azide. On the other hand, AIL8, as the control group was totally inert to the azide gases used. Not surprisingly, AIL7 can also readily undergo the Diels-Alder [4 + 2] cycloaddition reaction with the cyclopentadiene gas [114]. 


\subsection{Chemoselective Sensing of Alkene Gases}

Later on, we incorporated a cyclopentadiene group in AIL9 and a maleimide dienophile group in AIL10 for QCM studies of its fast Diels-Alder [4 + 2] cycloaddition reactions with alkene and diene gases, respectively [115]. Sensing by AIL9 was tested on five alkene gas molecules (1-pentene, cyclopentene, methyl acrylate, acrolein, acryloyl chloride), with acryloyl chloride producing the largest response in frequency drop. In addition, right after the first [4+2] cycloaddition reaction to afford the Diels-Alder adduct, the dual functionalized acryloyl chloride could be continued for a second consecutive reaction with an amine gas, a very fast Schotten-Baumann acylation, as demonstrated in Figure 12. Further on, AIL10 was synthesized for effective diene gas analysis, also, based upon the Diels-Alder reaction. As expected, the addition of $5 \mathrm{~mol} \% \mathrm{Sc}(\mathrm{OTf})_{3}$ Lewis acid further promoted the Diels-Alder reaction and a linear QCM frequency response with increase of concentration of cyclopentadiene was obtained. A sensitivity of detection of $1.5 \mathrm{ppb}$ at $\Delta F=-1 \mathrm{~Hz}$ was determined [115]. Next, among three other dienes (2,3-dimethyl-1,3-butadiene, cyclohexadiene and isoprene) investigated, AIL10 was also able to demonstrate high specificity to cyclopentadiene gas due to the fact that only it adopts a coplanar s-cis conformation [115].

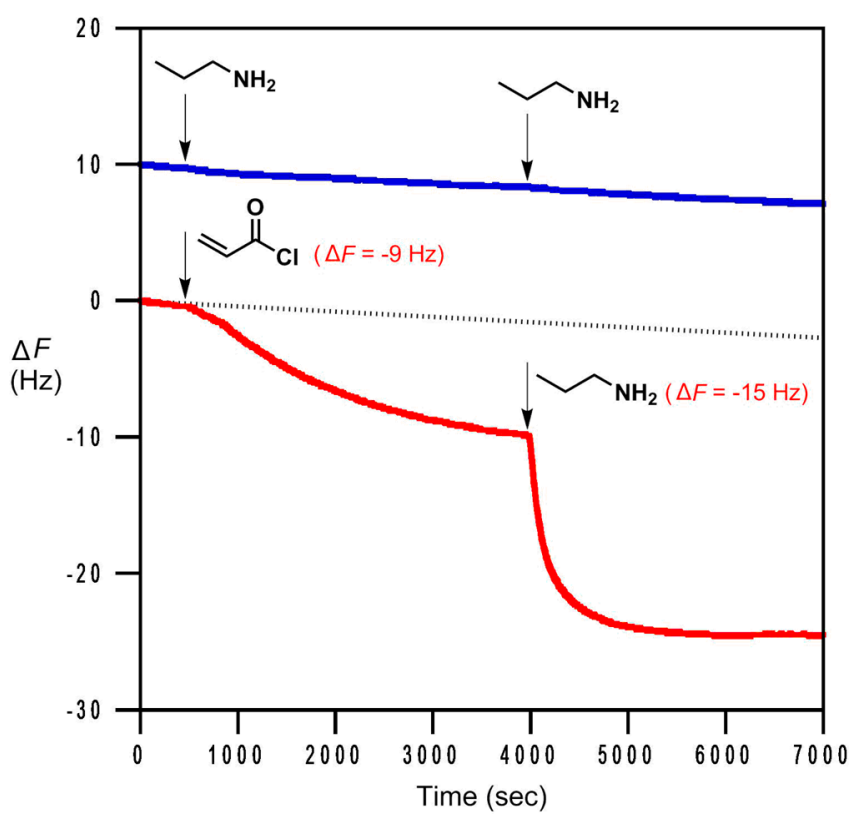

Figure 12. Detection of acryloyl chloride and propylamine (503 ppb each) was achieved by AIL9. Acryloyl chloride was injected at $500 \mathrm{~s}$ while propylamine was at $4000 \mathrm{~s}$. The QCM sensorgrams for two injections of propylamine gas purposely shifted vertically by $10 \mathrm{~Hz}$ for clarity [112].

\subsection{Chemoselective Sensing of Chemical Warfare Agent Mimics}

In 2018, to counter with gaseous chemical warfare agents (CWAs), AIL11 were designed and synthesized specifically for vapor detection of nerve agents (G-agents) mimics, diethyl chlorophosphate (DCP) and dimethyl chlorophosphate (DMCP), in our laboratory [116]. The mechanism of reaction involved the highly reactive azopyridine on AIL11, which serves as a nucleophile to undergo substitution reaction. The resulting frequency changes, along with the color change in azobenzene chromophore, were analyzed for quantitative measurements. The sensitivity of detection of AIL11 for $\mathrm{DCP}$ was determined to be $20 \mathrm{ppb}$ at $\Delta F=-5 \mathrm{~Hz}$. AIL11 displays chemoselectivity to decipher DCP and its analogous, more volatile dimethyl chlorophosphate DMCP, from common VOCs (Figure 13). However, in retrospect to its successful detection of DCP and DMCP vapor, AIL11 was found to be not reactive enough at ambient temperature to detect the vapor of 2-chloroethyl ethyl sulfide (CEES), a blister sulfur mustard (HD) mimic, due to the poor electrophilicity of CEES. Further studies are needed so that the appropriate modification can be made for its trace analysis. 


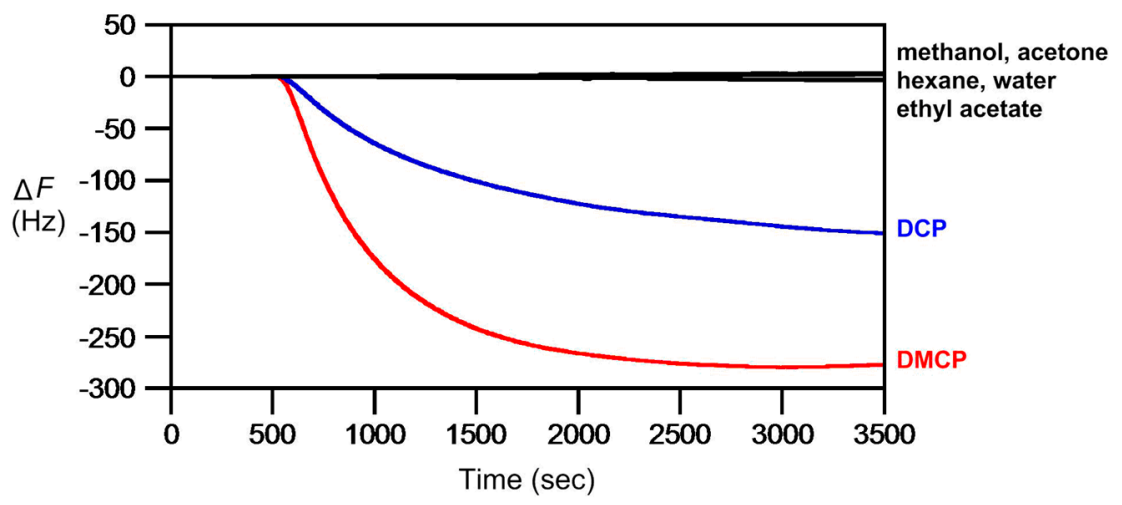

Figure 13. Chemoselective detection of common VOCs (water, ethyl acetate, hexane, methanol, acetone), DMCP and DCP at 526 ppb each by QCM thin-coated with AIL11 (2.2 nL each, $200 \mathrm{~nm}$ thickness). Carrier gas $\left(\mathrm{N}_{2}\right)$ had a flow rate of $3 \mathrm{~mL} / \mathrm{min}$ and analyte injection was made at $500 \mathrm{~s}$.

\section{Conclusions and Outlook}

Real-time analysis of gaseous molecules remains a challenging task even with current state-of-the-art analytical tools. Broadly speaking, methods for gas detection can be separated into two parts. Spectroscopic and spectrometric methods are powerful tools to provide high sensitivity in detection, yet the shortcomings of their large sizes in instruments, immobility and relatively expensive cost make them unsuitable for immediate analysis [118]. On the other hand, inspired by the mammalian olfactory system, various concepts of electronic nose have been employed and developed. These conductivity and piezoelectric methods involved the collection of highly selective sensors to comprise an array for analysis of gaseous molecules via pattern recognition or any other classification algorithm. However, this seem-to-be ideal solution has yet to be achieved due to the fact that compounds of similar structures can be indistinguishable for most sensors and other limiting factors such as high operating temperatures for MOSs make them less straightforward for use.

AIL-on-QCM for chemoselective gas analysis has the potential to provide an alternative sensing system. Though subject to interference, QCM remains to be an electrochemical device that can provide a highly sensitive platform. The incorporation of AILs embedded with the unique chemical properties on QCM quartz electrodes make it a promising tool for array sensing of gas mixtures. Also to be noted are the further studies needed to address factors that may affect changes in the QCM resonant frequency, such as temperature and humidity. In addition, better engineering in functional groups is needed to assure competitive reactions with ionic liquids will not occur. Albeit idealization to mimic that of a dog's nose is still beyond reach, the envision of a collection of AILs and perhaps a hybrid gas sensing system to complement each other may regard as a big step forward. After all, at the moment, not one method is satisfactory for all demands [117].

Author Contributions: Resources \& Discussion, I-N.C; Writing-Original Draft Preparation, A.C.; Writing-Review \& Editing, H.-Y.L. and Y.-H.C.; Project Administration, Y.-H.C.; Funding Acquisition, Y.-H.C.

Funding: This research was funded by the Ministry of Science and Technology of Taiwan (ROC) grant numbers MOST106-2113-M-194-006-MY3, MOST103-2113-M-194-002-MY3 and NSC100-2113-M-194-003-MY3.

Acknowledgments: We are indebted to those group members and collaborators who have helped develop our ionic liquid program through their experimental and intellectual contributions (M.-C. Tseng, Y.-P. Chang, Y. Shi, L. Shi, N. Li, M.-J. Tseng, J. Lo, C.-Y. Chen, H.-T. Cheng, Z. Li, S. Subbiah, V. Srinivasadesikan, K.-H. Li, C.-C. Hwang, T.-C. Yuan, S.-H. Jhou, C.-K. Huang, T.-H. Hsu, Y.-L. Liu, M.-J. Shen, H.-Y. Yang, Y.-W. Chu, S.-K. Hsiao, W.-H. Chen, C.-W. Chen, Y.-L. Lin, H.-C. Kan, W.-C. Chuang, C.-Y. Lai, J.-Y. Cheng, Y.-M. Liang, H.-F. Fu, L.-Y. Hsieh, Y.-H. Yen, P.-Y. Li, J.-C. Hsu, G.-Y. Yang, F.-M. Kuo).

Conflicts of Interest: The authors declare no conflict of interest. 


\section{References}

1. Tassopoulos, C.N.; Barnett, D.; Russell Fraser, T. Breath-acetone and blood-sugar measurements in diabetes. Lancet 1969, 293, 1282-1286. [CrossRef]

2. Teranishi, R.; Mon, T.R.; Robinson, A.B.; Cary, P.; Pauling, L. Gas chromatography of volatiles from breath and urine. Anal. Chem. 1972, 44, 18-20. [CrossRef] [PubMed]

3. Davies, S.; Spanel, P.; Smith, D. Quantitative analysis of ammonia on the breath of patients in end-stage renal failure. Kidney Int. 1997, 52, 223-228. [CrossRef] [PubMed]

4. Gasparri, R.; Santonico, M.; Valentini, C.; Sedda, G.; Borri, A.; Petrella, F.; Maisonneuve, P.; Pennazza, G.; D'Amico, A.; Di Natale, C.; et al. Volatile signature for the early diagnosis of lung cancer. J. Breath Res. 2016, 10, 016007. [CrossRef] [PubMed]

5. Nardi-Agmon, I.; Peled, N. Exhaled breath analysis for the early detection of lung cancer: Recent developments and future prospects. Lung Cancer Targets Ther. 2017, 8, 31-38. [CrossRef] [PubMed]

6. Hua, Q.; Zhu, Y.; Liu, H. Detection of volatile organic compounds in exhaled breath to screen lung cancer: A systematic review. Future Oncol. 2018, 14, 1647-1662. [CrossRef] [PubMed]

7. Gasparri, R.; Romano, R.; Sedda, G.; Borri, A.; Petrella, F.; Galetta, D.; Casiraghi, M.; Spaggiari, L. Diagnostic biomarkers for lung cancer prevention. J. Breath Res. 2018, 12, 027111. [CrossRef] [PubMed]

8. Heaney, L.M.; Lindley, M.R. Translation of exhaled breath volatile analyses to sport and exercise applications. Metabolomics 2017, 13, 139. [CrossRef]

9. Ali, S.B.; Ghatak, B.; Gupta, S.D.; Debabhuti, N.; Chakraborty, P.; Sharma, P.; Ghosh, A.; Tudu, B.; Mitra, S.; Sarkar, M.P.; et al. Detection of 3-carene in mango using a quartz crystal microbalance sensor. Sens. Actuator B 2016, 230, 791-800. [CrossRef]

10. Ali, S.B.; Ghatak, B.; Debabhuti, N.; Sharma, P.; Ghosh, A.; Tudu, B.; Bhattacharya, N.; Bandyopadhyay, R. Detection of $\beta$-caryophyllene in mango using a quartz crystal microbalance sensor. Sens. Actuator B 2018, 255, 3064-3073. [CrossRef]

11. Loutfi, A.; Coradeschi, S.; Mani, G.K.; Shankar, P.; Rayappan, J.B.B. Electronic noses for food quality: A review. J. Food Eng. 2015, 144, 103-111. [CrossRef]

12. Wojnowski, W.; Majchrzak, T.; Dymerski, T.; Gębicki, J.; Namieśnik, J. Electronic noses: Powerful tools in meat quality assessment. Meat Sci. 2017, 131, 119-131. [CrossRef] [PubMed]

13. Farneti, B.; Alarcón, A.A.; Cristescu, S.M.; Costa, G.; Harren, F.J.M.; Holthuysen, N.T.E.; Woltering, E.J. Aroma volatile release kinetics of tomato genotypes measured by ptr-ms following artificial chewing. Food Res. Int. 2013, 54, 1579-1588. [CrossRef]

14. Yamazoe, N. Toward innovations of gas sensor technology. Sens. Actuator B 2005, 108, 2-14. [CrossRef]

15. Fonollosa, J.; Solórzano, A.; Marco, S. Chemical sensor systems and associated algorithms for fire detection: A review. Sensors 2018, 18, 553. [CrossRef] [PubMed]

16. Schütze, A.; Reimann, P. Fire detection in coal mines based on semiconductor gas sensors. Sens. Rev. 2012, 32, 47-58.

17. Lefferts, M.J.; Castell, M.R. Vapour sensing of explosive materials. Anal. Methods 2015, 7, $9005-9017$. [CrossRef]

18. Wales, D.J.; Grand, J.; Ting, V.P.; Burke, R.D.; Edler, K.J.; Bowen, C.R.; Mintova, S.; Burrows, A.D. Gas sensing using porous materials for automotive applications. Chem. Soc. Rev. 2015, 44, 4290-4321. [CrossRef] [PubMed]

19. Dweik, R.A.; Amann, A. Exhaled breath analysis: The new frontier in medical testing. J. Breath Res. 2008, 2, 030301. [CrossRef] [PubMed]

20. American Chemical Society National Historic Chemical Landmarks. The Keeling Curve. Available online: http:/ / www.acs.org/content/acs/en/education/whatischemistry/landmarks/keeling-curve.html (accessed on 14 August 2018).

21. Pauling, L.; Robinson, A.B.; Teranishi, R.; Cary, P. Quantitative analysis of urine vapor and breath by gas-liquid partition chromatography. Proc. Natl. Acad. Sci. USA 1971, 68, 2374. [CrossRef] [PubMed]

22. Timofeyev, Y.; Virolainen, Y.; Makarova, M.; Poberovsky, A.; Polyakov, A.; Ionov, D.; Osipov, S.; Imhasin, H. Ground-based spectroscopic measurements of atmospheric gas composition near saint petersburg (russia). J. Mol. Spectrosc. 2016, 323, 2-14. [CrossRef] 
23. Stockwell, C.E.; Yokelson, R.J.; Kreidenweis, S.M.; Robinson, A.L.; DeMott, P.J.; Sullivan, R.C.; Reardon, J.; Ryan, K.C.; Griffith, D.W.T.; Stevens, L. Trace gas emissions from combustion of peat, crop residue, domestic biofuels, grasses and other fuels: Configuration and fourier transform infrared (FTIR) component of the fourth fire lab at missoula experiment (FLAME-4). Atmos. Chem. Phys. 2014, 14, 9727-9754. [CrossRef]

24. Platt, U.; Stutz, J. Evaluation of DOAS Spectra, Sensitivity, and Detection Limits. In Differential Absorption Spectroscopy: Principles and Applications; Platt, U., Stutz, J., Eds.; Springer: Berlin/Heidelberg, Germany, 2008; pp. 287-328, ISBN 978-3-540-21193-8.

25. Xu, M.; Tang, Z.; Duan, Y.; Liu, Y. GC-based techniques for breath analysis: Current status, challenges and prospects. Crit. Rev. Anal. Chem. 2016, 46, 291-304. [CrossRef] [PubMed]

26. Belardi, R.P.; Pawliszyn, J.B. Application of chemically modified fused silica fibers in the extraction of organics from water matrix samples and their rapid transfer to capillary columns. Water Poll. Res. J. Can. 1989, 24, 179-191.

27. Devasurendra, A.M.; Zhang, C.; Young, J.A.; Viranga Tillekeratne, L.M.; Anderson, J.L.; Kirchhoff, J.R. Electropolymerized pyrrole-based conductive polymeric ionic liquids and their application for solid-phase microextraction. ACS Appl. Mater. Interfaces 2017, 9, 24955-24963. [CrossRef] [PubMed]

28. Young, J.A.; Zhang, C.; Devasurendra, A.M.; Viranga Tillekeratne, L.M.; Anderson, J.L.; Kirchhoff, J.R. Conductive polymeric ionic liquids for electroanalysis and solid-phase microextraction. Anal. Chim. Acta 2016, 910, 45-52. [CrossRef] [PubMed]

29. Doran, G.S.; Deans, R.; De Filippis, C.; Kostakis, C.; Howitt, J.A. Air quality inside police drug safes and drug storage areas. J. Anal. Toxicol. 2018, 42, 360-364. [CrossRef] [PubMed]

30. Saasa, V.; Malwela, T.; Beukes, M.; Mokgotho, M.; Liu, C.-P.; Mwakikunga, B. Sensing technologies for detection of acetone in human breath for diabetes diagnosis and monitoring. Diagnostics 2018, 8, 12. [CrossRef] [PubMed]

31. Dryahina, K.; Smith, D.; Španěl, P. Quantification of volatile compounds released by roasted coffee by selected ion flow tube mass spectrometry. Rapid Commun. Mass Spectrom. 2018, 32, 739-750. [CrossRef] [PubMed]

32. Spanel, P.; Smith, D. Quantification of trace levels of the potential cancer biomarkers formaldehyde, acetaldehyde and propanol in breath by sift-ms. J. Breath Res. 2008, 2, 046003. [CrossRef] [PubMed]

33. Blake, R.S.; Monks, P.S.; Ellis, A.M. Proton-transfer reaction mass spectrometry. Chem. Rev. 2009, 109, 861-896. [CrossRef] [PubMed]

34. Majchrzak, T.; Wojnowski, W.; Lubinska-Szczygeł, M.; Różańska, A.; Namieśnik, J.; Dymerski, T. PTR-MS and GC-MS as complementary techniques for analysis of volatiles: A tutorial review. Anal. Chim. Acta 2018. [CrossRef]

35. Sun, Y.-F.; Liu, S.-B.; Meng, F.-L.; Liu, J.-Y.; Jin, Z.; Kong, L.-T.; Liu, J.-H. Metal oxide nanostructures and their gas sensing properties: A review. Sensors 2012, 12, 2610-2631. [CrossRef] [PubMed]

36. Deshmukh, S.; Bandyopadhyay, R.; Bhattacharyya, N.; Pandey, R.A.; Jana, A. Application of electronic nose for industrial odors and gaseous emissions measurement and monitoring-An overview. Talanta 2015, 144, 329-340. [CrossRef] [PubMed]

37. Kanan, M.S.; El-Kadri, M.O.; Abu-Yousef, A.I.; Kanan, C.M. Semiconducting metal oxide based sensors for selective gas pollutant detection. Sensors 2009, 9, 8158-8196. [CrossRef] [PubMed]

38. Schaller, E.; Bosset, J.O.; Escher, F. 'Electronic noses' and their application to food. LWT-Food Sci. Technol. 1998, 31, 305-316. [CrossRef]

39. Núñez Carmona, E.; Sberveglieri, V.; Ponzoni, A.; Galstyan, V.; Zappa, D.; Pulvirenti, A.; Comini, E. Detection of food and skin pathogen microbiota by means of an electronic nose based on metal oxide chemiresistors. Sens. Actuator B 2017, 238, 1224-1230. [CrossRef]

40. Poloju, M.; Jayababu, N.; Ramana Reddy, M.V. Improved gas sensing performance of al doped zno/cuo nanocomposite based ammonia gas sensor. Mater. Sci. Eng. B 2018, 227, 61-67. [CrossRef]

41. Dey, A. Semiconductor metal oxide gas sensors: A review. Mater. Sci. Eng. B 2018, 229, 206-217. [CrossRef]

42. Korotcenkov, G.; Cho, B.K. Metal oxide composites in conductometric gas sensors: Achievements and challenges. Sens. Actuator B 2017, 244, 182-210. [CrossRef]

43. Wang, L.; Han, Y.; Feng, X.; Zhou, J.; Qi, P.; Wang, B. Metal-organic frameworks for energy storage: Batteries and supercapacitors. Coord. Chem. Rev. 2016, 307, 361-381. [CrossRef] 
44. Wang, H.; Zhu, Q.-L.; Zou, R.; Xu, Q. Metal-organic frameworks for energy applications. Chem 2017, 2, 52-80. [CrossRef]

45. Xu, G.; Nie, P.; Dou, H.; Ding, B.; Li, L.; Zhang, X. Exploring metal organic frameworks for energy storage in batteries and supercapacitors. Mater. Today 2017, 20, 191-209. [CrossRef]

46. Yi, F.-Y.; Chen, D.; Wu, M.-K.; Han, L.; Jiang, H.-L. Chemical sensors based on metal-organic frameworks. ChemPlusChem 2016, 81, 675-690. [CrossRef]

47. Stassen, I.; Burtch, N.; Talin, A.; Falcaro, P.; Allendorf, M.; Ameloot, R. An updated roadmap for the integration of metal-organic frameworks with electronic devices and chemical sensors. Chem. Soc. Rev. 2017, 46, 3185-3241. [CrossRef] [PubMed]

48. Achmann, S.; Hagen, G.; Kita, J.; Malkowsky, M.I.; Kiener, C.; Moos, R. Metal-organic frameworks for sensing applications in the gas phase. Sensors 2009, 9, 1574-1589. [CrossRef] [PubMed]

49. Zhang, Y.; Chen, Y.; Zhang, Y.; Cong, H.; Fu, B.; Wen, S.; Ruan, S. A novel humidity sensor based on $\mathrm{NH}_{2}$-MIL-125(Ti) metal organic framework with high responsiveness. J. Nanopart. Res. 2013, 15, 2014. [CrossRef]

50. Guo, K.; Zhao, L.; Yu, S.; Zhou, W.; Li, Z.; Li, G. A water-stable proton-conductive barium(II)-organic framework for ammonia sensing at high humidity. Inorg. Chem. 2018, 57, 7104-7112. [CrossRef] [PubMed]

51. Sun, Z.; Yu, S.; Zhao, L.; Wang, J.; Li, Z.; Li, G. A highly stable two-dimensional copper(II)-organic framework for proton conduction and ammonia impedance sensing. Chem. Eur. J. 2018, 24, 10829-10839. [CrossRef] [PubMed]

52. Chen, E.-X.; Yang, H.; Zhang, J. Zeolitic imidazolate framework as formaldehyde gas sensor. Inorg. Chem. 2014, 53, 5411-5413. [CrossRef] [PubMed]

53. Campbell, M.G.; Liu, S.F.; Swager, T.M.; Dincă, M. Chemiresistive sensor arrays from conductive 2D metal-organic frameworks. J. Am. Chem. Soc. 2015, 137, 13780-13783. [CrossRef] [PubMed]

54. Smith, M.K.; Jensen, K.E.; Pivak, P.A.; Mirica, K.A. Direct self-assembly of conductive nanorods of metal-organic frameworks into chemiresistive devices on shrinkable polymer films. Chem. Mater. 2016, 28, 5264-5268. [CrossRef]

55. Campbell, G.M.; Dincă, M. Metal-organic frameworks as active materials in electronic sensor devices. Sensors 2017, 17, 1108. [CrossRef] [PubMed]

56. Kreno, L.E.; Leong, K.; Farha, O.K.; Allendorf, M.; Van Duyne, R.P.; Hupp, J.T. Metal-organic framework materials as chemical sensors. Chem. Rev. 2012, 112, 1105-1125. [CrossRef] [PubMed]

57. Lin, R.-B.; Liu, S.-Y.; Ye, J.-W.; Li, X.-Y.; Zhang, J.-P. Photoluminescent metal-organic frameworks for gas sensing. Adv. Sci. 2016, 3, 1500434. [CrossRef] [PubMed]

58. Cui, Y.; Yue, Y.; Qian, G.; Chen, B. Luminescent functional metal-organic frameworks. Chem. Rev. 2012, 112, 1126-1162. [CrossRef] [PubMed]

59. Hu, Z.; Deibert, B.J.; Li, J. Luminescent metal-organic frameworks for chemical sensing and explosive detection. Chem. Soc. Rev. 2014, 43, 5815-5840. [CrossRef] [PubMed]

60. Kumar, P.; Deep, A.; Kim, K.-H. Metal organic frameworks for sensing applications. Trends Anal. Chem. 2015, 73, 39-53. [CrossRef]

61. Pandey, S. Highly sensitive and selective chemiresistor gas/vapor sensors based on polyaniline nanocomposite: A comprehensive review. J. Sci. Adv. Mater. Dev. 2016, 1, 431-453. [CrossRef]

62. Bai, H.; Shi, G.Q. Gas sensors based on conducting polymers. Sensors 2007, 7, 267-307. [CrossRef]

63. Song, E.; Choi, J.W. Conducting polyaniline nanowire and its applications in chemiresistive sensing. Nanomaterials 2013, 3, 498-523. [CrossRef] [PubMed]

64. Cuypers, W.; Lieberzeit, P.A. Combining two selection principles: Sensor arrays based on both biomietic recognition and chemometrics. Front Chem. 2018, 6, 268. [CrossRef] [PubMed]

65. Ballantine, D.S.; Martin, S.J.; Ricco, A.J.; Frye, G.C.; Wohltjen, H.; White, R.M.; Zellers, E.T. Fundamentals of acoustic waves. In Acoustic Wave Sensors; Ballantine, D.S., Martin, S.J., Ricco, A.J., Frye, G.C., Wohltjen, H., White, R.M., Zellers, E.T., Eds.; Academic Press: San Diego, CA, USA, 1997; Chapter 2; pp. 10-35.

66. Wohltjen, H.; Dessy, R. Surface acoustic wave probe for chemical analysis. I. Introduction and instrument description. Anal. Chem. 1979, 51, 1458-1464. [CrossRef]

67. Go, D.B.; Atashbar, M.Z.; Ramshani, Z.; Chang, H.-C. Surface acoustic wave devices for chemical sensing and microfluidics: A review and perspective. Anal. Methods 2017, 9, 4112-4134. [CrossRef] [PubMed] 
68. Mujahid, A.; Dickert, L.F. Surface acoustic wave (SAW) for chemical sensing applications of recognition layers. Sensors 2017, 17, 2716. [CrossRef] [PubMed]

69. Devkota, J.; Ohodnicki, R.P.; Greve, W.D. SAW sensors for chemical vapors and gases. Sensors 2017, $17,801$. [CrossRef] [PubMed]

70. Ragavan, K.V.; Kumar, S.; Swaraj, S.; Neethirajan, S. Advances in biosensors and optical assays for diagnosis and detection of malaria. Biosens. Bioelectron. 2018, 105, 188-210. [CrossRef] [PubMed]

71. Ly, T.N.; Park, S.; Park, S.J. Detection of HIV-1 antigen by quartz crystal microbalance using gold nanoparticles. Sens. Actuator B 2016, 237, 452-458. [CrossRef]

72. Arif, S.; Qudsia, S.; Urooj, S.; Chaudry, N.; Arshad, A.; Andleeb, S. Blueprint of quartz crystal microbalance biosensor for early detection of breast cancer through salivary autoantibodies against ATP6AP1. Biosens. Bioelectron. 2015, 65, 62-70. [CrossRef] [PubMed]

73. Pohanka, M. Overview of piezoelectric biosensors, immunosensors and DNA sensors and their applications. Materials 2018, 11, 448. [CrossRef] [PubMed]

74. Bragazzi, N.L.; Amicizia, D.; Panatto, D.; Tramalloni, D.; Valle, I.; Gasparini, R. Quartz crystal microbalance (QCM) for public health: An overview of its applications. In Advances in Protein Chemistry and Structural Biology; Donev, R., Ed.; Academic Press: San Diego, CA, USA, 2015; Volume 101, pp. 149-211.

75. Chen, J.Y.; Penn, L.S.; Xi, J. Quartz crystal microbalance: Sensing cell-substrate adhesion and beyond. Biosens. Bioelectron. 2018, 99, 593-602. [CrossRef] [PubMed]

76. Skládal, P. Piezoelectric biosensors. Trends Anal. Chem. 2016, 79, 127-133. [CrossRef]

77. Kurosawa, S.; Park, J.-W.; Aizawa, H.; Wakida, S.-I.; Tao, H.; Ishihara, K. Quartz crystal microbalance immunosensors for environmental monitoring. Biosens. Bioelectron. 2006, 22, 473-481. [CrossRef] [PubMed]

78. Qiao, X.; Zhang, X.; Tian, Y.; Meng, Y. Progresses on the theory and application of quartz crystal microbalance. Appl. Phys. Rev. 2016, 3, 031106. [CrossRef]

79. Sauerbrey, G. Verwendung von schwingquarzen zur wägung dünner schichten und zur mikrowägung. Z. Phys. 1959, 155, 206-222. [CrossRef]

80. Kanazawa, K.K.; Gordon, J.G. Frequency of a quartz microbalance in contact with liquid. Anal. Chem. 1985, 57, 1770-1771. [CrossRef]

81. Rodahl, M.; Kasemo, B. A simple setup to simultaneously measure the resonant frequency and the absolute dissipation factor of a quartz crystal microbalance. Rev. Sci. Instrum. 1996, 67, 3238-3241. [CrossRef]

82. Johannsmann, D. Viscoelastic, mechanical and dielectric measurements on complex samples with the quartz crystal microbalance. Phys. Chem. Chem. Phys. 2008, 10, 4516-4534. [CrossRef] [PubMed]

83. Hussain, M.; Rupp, F.; Wendel, H.P.; Gehring, F.K. Bioapplications of acoustic crystals, a review. Trends Anal. Chem. 2018, 102, 194-209. [CrossRef]

84. Ma, F.; Rehman, A.; Sims, M.; Zeng, X. Antimicrobial susceptibility assays based on the quantification of bacterial lipopolysaccharides via a label free lectin biosensor. Anal. Chem. 2015, 87, 4385-4393. [CrossRef] [PubMed]

85. Shpigel, N.; Levi, M.D.; Sigalov, S.; Girshevitz, O.; Aurbach, D.; Daikhin, L.; Pikma, P.; Marandi, M.; Jänes, A.; Lust, E.; et al. In situ hydrodynamic spectroscopy for structure characterization of porous energy storage electrodes. Nat. Mater. 2016, 15, 570. [CrossRef] [PubMed]

86. Dargel, V.; Shpigel, N.; Sigalov, S.; Nayak, P.; Levi, M.D.; Daikhin, L.; Aurbach, D. In situ real-time gravimetric and viscoelastic probing of surface films formation on lithium batteries electrodes. Nat. Commun. 2017, 8, 1389. [CrossRef] [PubMed]

87. Levi, M.D.; Shpigel, N.; Sigalov, S.; Dargel, V.; Daikhin, L.; Aurbach, D. In situ porous structure characterization of electrodes for energy storage and conversion by EQCM-D: A review. Electrochim. Acta 2017, 232, 271-284. [CrossRef]

88. Yu, L.; Huang, Y.; Jin, X.; Mason, A.J.; Zeng, X. Ionic liquid thin layer EQCM explosives sensor. Sens. Actuator B 2009, 140, 363-370. [CrossRef]

89. Emir Diltemiz, S.; Keçili, R.; Ersöz, A.; Say, R. Molecular imprinting technology in quartz crystal microbalance (QCM). Sensors 2017, 17, 454. [CrossRef] [PubMed]

90. Lay, B.; Kandjani, A.E.; Amin, M.H.; Kabir, K.M.M.; Ippolito, S.J.; Sabri, Y.M.; Bhargava, S.K. Galvanic replacement of colloidal monolayer crystal on a QCM device for selective detection of mercury vapor. Sens. Actuator B 2017, 250, 383-392. [CrossRef] 
91. Öztürk, S.; Kösemen, A.; Şen, Z.; Kılınç, N.; Harbeck, M. Poly(3-methylthiophene) thin films deposited electrochemically on QCMs for the sensing of volatile organic compounds. Sensors 2016, 16, 423. [CrossRef] [PubMed]

92. Ruifen, H.; Kaihuan, Z.; Guokang, F.; Zhiyuan, L.; Guang, L. Development of a high-sensitivity plasticizer sensor based on a quartz crystal microbalance modified with a nanostructured nickel hydroxide film. Meas. Sci. Technol. 2015, 26, 055102.

93. Deng, F.; Chen, W.; Wang, J.; Wei, Z. Fabrication of a sensor array based on quartz crystal microbalance and the application in egg shelf life evaluation. Sens. Actuator B 2018, 265, 394-402. [CrossRef]

94. Jia, Y.; Yu, H.; Zhang, Y.; Dong, F.; Li, Z. Cellulose acetate nanofibers coated layer-by-layer with polyethylenimine and graphene oxide on a quartz crystal microbalance for use as a highly sensitive ammonia sensor. Colloids Surf. B 2016, 148, 263-269. [CrossRef] [PubMed]

95. Sun, P.; Armstrong, D.W. Ionic liquids in analytical chemistry. Anal. Chim. Acta 2010, 661, 1-16. [CrossRef] [PubMed]

96. Niedermeyer, H.; Hallett, J.P.; Villar-Garcia, I.J.; Hunt, P.A.; Welton, T. Mixtures of ionic liquids. Chem. Soc. Rev. 2012, 41, 7780-7802. [CrossRef] [PubMed]

97. Vekariya, R.L. A review of ionic liquids: Applications towards catalytic organic transformations. J. Mol. Liq. 2017, 227, 44-60. [CrossRef]

98. Ventura, S.P.M.; Silva, F.A.E.; Quental, M.V.; Mondal, D.; Freire, M.G.; Coutinho, J.A.P. Ionic-liquid-mediated extraction and separation processes for bioactive compounds: Past, present and future trends. Chem. Rev. 2017, 117, 6984-7052. [CrossRef] [PubMed]

99. Egorova, K.S.; Gordeev, E.G.; Ananikov, V.P. Biological activity of ionic liquids and their application in pharmaceutics and medicine. Chem. Rev. 2017, 117, 7132-7189. [CrossRef] [PubMed]

100. Watanabe, M.; Thomas, M.L.; Zhang, S.G.; Ueno, K.; Yasuda, T.; Dokko, K. Application of ionic liquids to energy storage and conversion materials and devices. Chem. Rev. 2017, 117, 7190-7239. [CrossRef] [PubMed]

101. Zhou, Y.; Qu, J. Ionic liquids as lubricant additives: A review. ACS Appl. Mater. Interfaces 2017, 9, 3209-3222. [CrossRef] [PubMed]

102. Wishart, J.F. Energy applications of ionic liquids. Energy Environ. Sci. 2009, 2, 956-961. [CrossRef]

103. Rehman, A.; Zeng, X. Methods and approaches of utilizing ionic liquids as gas sensing materials. RSC Adv. 2015, 5, 58371-58392. [CrossRef] [PubMed]

104. Liang, C.; Yuan, C.-Y.; Warmack, R.J.; Barnes, C.E.; Dai, S. Ionic liquids: A new class of sensing materials for detection of organic vapors based on the use of a quartz crystal microbalance. Anal. Chem. 2002, 74, 2172-2176. [CrossRef] [PubMed]

105. Jin, X.; Yu, L.; Garcia, D.; Ren, R.X.; Zeng, X. Ionic liquid high-temperature gas sensor array. Anal. Chem. 2006, 78, 6980-6989. [CrossRef] [PubMed]

106. Behera, K.; Pandey, S.; Kadyan, A.; Pandey, S. Ionic liquid-based optical and electrochemical carbon dioxide sensors. Sensors 2015, 15, 30487-30503. [CrossRef] [PubMed]

107. Che, S.; Dao, R.; Zhang, W.; Lv, X.; Li, H.; Wang, C. Designing an anion-functionalized fluorescent ionic liquid as an efficient and reversible turn-off sensor for detecting $\mathrm{SO}_{2}$. Chem. Commun. 2017, 53, 3862-3865. [CrossRef] [PubMed]

108. Wasilewski, T.; Gębicki, J.; Kamysz, W. Prospects of ionic liquids application in electronic and bioelectronic nose instruments. Trends Anal. Chem. 2017, 93, 23-36. [CrossRef]

109. Gebicki, J. Application of ionic liquids in electronic nose instruments. In Analytical Applications of Ionic Liquids; Koel, M., Ed.; World Scientific: London, UK, 2016; pp. 339-360.

110. Tseng, M.-C.; Chu, Y.-H. Chemoselective gas sensing ionic liquids. Chem. Commun. 2010, 46, $2983-2985$. [CrossRef] [PubMed]

111. Li, H.-Y.; Hsu, T.-H.; Chen, C.-Y.; Tseng, M.-C.; Chu, Y.-H. Exploring silver ionic liquids for reaction-based gas sensing on a quartz crystal microbalance. Analyst 2015, 140, 6245-6249. [CrossRef] [PubMed]

112. Liu, Y.-L.; Tseng, M.-C.; Chu, Y.-H. Sensing ionic liquids for chemoselective detection of acyclic and cyclic ketone gases. Chem. Commun. 2013, 49, 2560-2562. [CrossRef] [PubMed]

113. Li, H.-Y.; Chu, Y.-H. Exploiting solvate ionic liquids for amine gas analysis on a quartz crystal microbalance. Anal. Chem. 2017, 89, 5186-5192. [CrossRef] [PubMed]

114. Tseng, M.-C.; Chu, Y.-H. Reaction-based azide gas sensing with tailored ionic liquids measured by quartz crystal microbalance. Anal. Chem. 2014, 86, 1949-1952. [CrossRef] [PubMed] 
115. Hsu, T.-H.; Chiang, S.-J.; Chu, Y.-H. Quartz crystal microbalance analysis of Diels-Alder reactions of alkene gases to functional ionic liquids on chips. Anal. Chem. 2016, 88, 10837-10841. [CrossRef] [PubMed]

116. Chen, C.-Y.; Li, K.-H.; Chu, Y.-H. Reaction-based detection of chemical warfare agent mimics with affinity ionic liquids. Anal. Chem. 2018, 90, 8320-8325. [CrossRef] [PubMed]

117. Spinelle, L.; Gerboles, M.; Kok, G.; Persijn, S.; Sauerwald, T. Review of portable and low-cost sensors for the ambient air monitoring of benzene and other volatile organic compounds. Sensors 2017, 17, 1520. [CrossRef] [PubMed]

118. Chang, Y.-P.; Liu, W.-C.; Tseng, M.-C.; Chu, Y.-H. Ionic liquids tailored for reaction-based gas sensing on quartz crystal microbalance. Rev. Anal. Chem. 2015, 34, 77-86. [CrossRef]

C 2018 by the authors. Licensee MDPI, Basel, Switzerland. This article is an open access article distributed under the terms and conditions of the Creative Commons Attribution (CC BY) license (http://creativecommons.org/licenses/by/4.0/). 